\title{
DAYA TARIK BAGI WISATAWAN BERSEPEDA DI PEDESAAN BALI
}

\author{
Anak Agung Gde Oka Geria ${ }^{1}$, I Gusti Ngurah Agung Suprastayasa ${ }^{2}$ \\ ${ }^{\text {I} P o l i t e k n i k ~ P a r i w i s a t a ~ B a l i, ~ B a d u n g, ~ I n d o n e s i a, ~ E m a i l: d o k a g e r i a @ g m a i l . c o m ~}$ \\ ${ }^{2}$ Politeknik Pariwisata Bali, Badung, Indonesia, Email:agung.suprastayasa@ppb.ac.id
}

\begin{abstract}
ABSTRAK
Artikel ini merupakan penelitian kualitatif deskriptif yang bertujuan untuk mengetahui minat dan fasilitas pendukung pariwisata yang dibutuhkan oleh wisatawan mancanegara yang mengikuti paket wisata bersepeda di Desa Petak Kaja. Penelitian ini merupakan jenis pengembangan pariwisata pedesaan berdasarkan teori pariwisata berbasis masyarakat yang berkelanjutan. Data diperoleh melalui wawancara terhadap 15 orang peserta program wisata bersepeda dari sebuah biro perjalanan. Hasil penelitian menunjukkan bahwa wisatawan yang mengikuti paket wisata bersepeda ini menemukan beberapa atribut desa seperti masyarakat sekitar, kehidupan sehari-hari, keindahan pemandangan, persawahan desa, upacara adat, rumah desa, pura dan sekolah yang menarik. Sedangkan kebersihan lingkungan, lalu lintas desa dan kualitas jalan desa kurang menarik. Keindahan lanskap paling menarik dan lalu lintas desa paling tidak menarik. Mereka sangat membutuhkan toilet yang bersih dan higienis serta air yang jernih dan berkualitas yang dapat mereka gunakan di rumah-rumah penduduk setempat. Hasil penelitian ini memberi implikasi praktis berupa perlunya peningkatan berbagai fasilitas untuk menunjang kegiatan bersepeda di Desa tersebut.
\end{abstract}

Kata Kunci: daya tarik; wisata bersepeda; wisata perdesaan;

\section{POINTS OF INTERESTS FOR SYCLING TOURISTS IN A RURAL BALINESE VILLAGE}

\begin{abstract}
This writing is descriptive qualitative study which is aimed to identify the tourism interests and supporting facilities needed by international tourists taking a cycling package tour in Petak Kaja Village. The study is a type of village or rural area tourism development based on the theory of sustainable community based tourism. Data were collected through interview with 15 tourists taking cycling tour program in Peta Village. The result shows that the tourists taking part in this cycling package tour found some village attributes such as the local people, their daily life, the landscape beauty, village rice fields, local ceremonies, village houses, temples and schools are interesting. Meanwhile environment cleanliness, village traffic and quality of village roads are less interesting. The landscape beauty is most interesting and the village traffic is the least interesting. They urgently need clean and hygienic toilets and clear and good quality of water which they can use in the houses of local people. The results
\end{abstract}


showed brought about some practical implication namely the need to provide and improve the facilities needed by the tourist and the cleanliness.

Keywords : point of interests, sycling tour, village tourism

\section{Copyright (02021. UHN IGB Sugriwa Denpasar. All Right Reserved}

\section{PENDAHULUAN}

Pemerintah Daerah Bali telah menjadikan sektor pariwisata sebagai sektor unggulan dalam pembangunan di pulau ini. Industri pariwisata di Bali telah memberikan kontribusi penting bagi perekonomian Bali dan juga Indonesia, khususnya untuk pendapatan devisa, dan lapangan kerja. (Suprastayasa, 2007). Sektor ini daharapkan mampu memainkan peranan penting dalam menyejahterakan rakyat. Undang Undang N0 10 tahun 2009 tentang kepariwisataan Nasional menyatakan bahwa pembangunan sekor pariwisata diharapkan mempu: (1) meningkatkan pertumbuhan ekonomi dan kesejahteraan rakyat; (2) mengatasi pengangguran dan mengentaskan kemiskinan; (3) mengangkat citra bangsa dan mempererat persahabatan antar bangsa dan (4) memupuk rasa cinta tanah air, memperkokoh jati diri dan kesatuan bangsa.

Pulau Bali telah lama terkenal sebagai daerah tujuan wisata. Wisatawan yang mengunjungi Bali juga ikut berperan dalam mempromosikan keunikan pulau ini. Wisatawan tersebut tentunya berasal dari berbagai profesi, beberapa diantaranya adalah sosiolog, antropolog, pelukis, sastrawan dan ilmuwan lainnya yang kemudaian karya-karya mereka menjadi cerita dari mulut ke mulut yang membuat Bali semakin terkenal di dunia (Wiranatha dan Pujaastawa, 2008)

Maraknya isu pemanasan global dewasa ini yang mendapat respon besar-besaran dari para pencinta alam melalaui propagandapropaganda "back to nature" dan "go green", ternyata juga memberi pengaruh terhadap perkembangan pariwisata dunia umumnya dan pariwisata Bali khususnya. Merespon hal ini para pelaku bisnis pariwisata di Bali semakin gencar menawarkan atraksi-atraksi wisata yang berhubungan dengan alam, yang meminimalisir penggunaan bahan bakar minyak bumi, serta lebih mengekplorasi keunikan budaya Bali. Pengembangan pariwisata Bali kemudian lebih mengarah ke pariwisata alternatif. Beberapa bentuk pariwisata alternatif yang sekarang sedang dikembangkan di Bali adalah: agrowisata, wisata alam, wisata pedesaan, wisata petualangan wisata olah raga, wisata kuliner khas Bali dan yang lainnya (Wiranatha, 2003).

Wisata bersepeda adalah salah satu bagian wisata alternatif yakni wisata olah raga yang juga merupakan satu bentuk respon dari propaganda go green dan back to nature tersebut. Wisata jenis ini juga sedang marak dikembangkan di Bali. Rute yang dilalui pada umumnya adalah jalan-jalan pedesaan yang ada di Bali. Wisata jenis ini dapat juga dikatagorikankan sebagai wisata pedesaan yaitu suatu kegiatan pariwisata di suatu wilayah yang menawarkan daya tarik wisata berupa keseluruhan suasana yang mencerminkan keaslian pedesaan. (Wirata, 2010). Selain di perdesaan, wisata bersepeda juga sedang dikembangkan di Sanur dalam mewujudkan pariwisata berkelanjutan (Wirawan, 2016).

Suasana pedesaan sendiri dapat mencakup beberapa hal yang layak mendapatkan perhatian seperti kehidupan social konomi, sosial budaya, adat-istiadat, arsitektur bangunan, maupun struktur tata ruang desa dari masyarakat setempat. Tidak banyak penelitian dan tulisan yang membahas tentang wisata alternatif khususnya di Bali. Wirata (2010) 
memaparkan pariwisata pedesaan sebagai paket wisata alternatif. Kasus Desa Wisata Taman Slau, mengidentifikasi kegiatankegiatan yang dilakukan oleh wisatawan yang mengikuti paket wisata trekking di banjar Taman Slau, desa Undisan, kabupaten Bangli. Di tahun yang sama Puspadi menggambarkan, Pariwisata Desa Berkelanjutan: Studi Kasus Desa Jatiluwih, Bali yang bertujuan untuk mengetahui pengaruh pembangunan wisata pedesaan terhadap aspek-aspek ekonomi, sosial budaya dan lingkungan.

Salah satu wisata bersepeda adalah kegiatan wisata yang rutenya melalui desa Petak Kaja, kecamatan Gianyar, kabupaten Gianyar, Bali. Desa Petak Kaja ini terletak sekitar dua belas kilometer dari Kota Gianyar. Desa ini bersebelahan dengan desa Selat, kecamatan Susut, Kabupaten Bangli. Kegiatan wisata bersepeda ini dimulai di desa Seribatu, kecamatan Susut, Kabupaten Bangli dan berhenti untuk istirahat dalam jangka waktu tertentu di bawah pohon beringin yang besar dan rindang di salah satu Banjar yang ada di lingkungan Desa Petak Kaja. Desa Petak Kaja ini terdiri dari empat banjar yaitu Banjar Petak, Banjar Mantering, Banjar Padpadan dan Banjar Panyembahan. Keempat banjar di desa ini dilalui oleh rute wisata bersepeda tersebut. Salah satu Pengelola dari layanan wisata bersepeda ini yang sering menggunakan lintasan di Desa Petaka Kaja ini sebagai rutenya adalah Bali Eco Cycling yang bermarkas di Jalan Raya Pengosekan Ubud, Bali. Wisata ini mulai beroperasi dari tahun 1999. Berdasarkan data dari pengelola tur ini, diketahui bahwa pada tahun 1912 rata-rata jumlah wisatawan yang mengikuti tur ini setiap harinya adalah 15 orang, tetapi pada tahun 2013 sampai dengan bulan Mei rata ratanya sudah mencapai 50 orang setiap hari, dan kemungkinan untuk meningkat masih sangat besar karena lonjakan pada bulan-bulan high season belum terjadi (http://baliecocycling.com/).

Walaupun sepertinya tidak ada sesuatu yang berbeda dan spesial yang dapat dinikmati oleh para wisatawan bersepeda di sepanjang rute di daerah pedesaan Petak Kaja ini, tetapi kuantitas wisatawan yang membeli paket wisata bersepeda ini dari hari ke hari semakin meningkat. Hal ini menimbulkan dua permasalahan pokok dalam upaya untuk menjadikan wisata ini berkelanjutan dan berkembang lebih berdasarkan asas pariwisata kerakyatan, yaitu: 1). Daya tarik apa saja yang diminati oleh wisatawan selama melakukan wisata bersepeda di desa Petak Kaja Gianyar dan 2). Sarana pendukung apa saja yang diinginkan oleh para wisatawan untuk tersedia demi kenyamanan mereka melakukan wisata bersepeda di daerah tersebut?

\section{LITERATUR REVIEW}

\section{Pariwisata Pedesaan dan Daya Tariknya}

Kata wisata dapat dterjemahkan dengan kata tour dalam bahasa Inggris yang berarti berjalan jalan untuk menikmati keindahan pemandangan. Kata pariwisata menurut etimologinya diambil dari bahasa Sansekerta yang terdiri dari dua suku kata yaitu pari dan wisata. Kata pari berarti halus atau memiliki tata karma yang tinggi. Yang dimaksudkan oleh kata pariwisata kemudian adalah melaksanakan suatu perjalanan atau kunjugan dengan bertata karma yang tinggi atau berbudi (Syafiie, 2009)

Pariwisata secara umum didifinisikan sebagai suatu aktifitas yang dilaksanakan oleh seseorang untuk berkunjung ke suatu daerah yang bukan merupakan tempat tinggalnya ataupun tempat bekerjanya dalam waktu tertentu untuk merasakan suatu kepuasan dan bersenang-senang. (Safiie, 2009)

Tren pengembangan pariwisata yang pada umumnya selalu dimulai dengan melibatkan para pemodal besar dan menomor-duakan keberadaan masyarakat local telah menjadi inspirasi bagi pengembangan pariwisata yang berbasis kerakyatan. Perencanaan pengembangan pariwisata jenis ini lebih dikenal dengan top- 
down planning. Korten (1986) menyebutkan bahwa di sektor pariwisata model pembangunan dengan menggunakan perencanaan dari bawah ke atas (bottom up planning) adalah sangat selaras dengan pengembangan pariwisata yang lebih memihak kepada masyarakat atau lebih dikenal dengan pariwisata kerakyatan. Paradigma ini mendapatkan beberapa sebutan seperti; pariwisata kerakyatan, pariwisata inti rakyat, community based management tourism, atau community management tourism.

Perkembagan pembangunan pariwisata seperti ini akhirnya mengarah kepada pengembangan dan pembangunan wisata pedesaan, atau desa wisata dalam bentuk pengembangan pariwisata berkelanjutan dengan pangsa pasar tersendiri (Adhisakti, 2000). Pengembangan pariwisata model modernisasi telah dianggap gagal untuk dilaksanakan di negara-negara berkembang termasuk di Indonesia karena memiliki banyak kelemahan yang selalu mendahulukan perkembangan bangunan fisik dan sangat kurang memperhatikan masalah sosial masyarakat. Bertolak dari hal ini maka perkembangan pariwisata beralih pada model pilihan lainnya yaitu pengembangan pariwisata kerakyatan yang bermuara pada pengembangan wisata pedesaan. Berpegang pada konsep ini kini desa-desa yang memiliki potensi pariwisata yang unik mulai didekati oleh para pelaku pariwisata maupun pemerintah daerah.

Pengembangan pariwisata pedesaan pada dasarnya adalah pengembangan suatu wilayah pedesaan dengan menggunakan potensi yang tersimpan pada masyarakat suatu desa tersebut. potensi-potensi tersebut dijadikan atribut-atribut produk wisata yang dikemas dalam suatu rangkaian pariwisata yang terpadu dengan mengusung tema tertentu. Maksud dari terpadu adalah desa mampu menyediakan produk-produk wisata yang dibutuhkan para wisatawan yang berkunjung ke desa tersebut baik atraksiatraksi yang merupakan daya tarik khas yang ada di desa tersebut serta berbagai fasilitas pendukungnya.

Departemen Budpar, 2001 memberikan sebuah batasan tentang pariwisata pedesaan yaitu; pengembangan suatu wilayah pedesaan sehingga memiliki kemampuan untuk menyediakan serta menawarkan keseluruhan suasana yang mencerminkan keaslian pedesaan, baik dari segi kehidupan sosial ekonomi, sosial budaya, adat istiadat keseharian, memilik struktur bangunan dan tata ruang desa yang khas atau kegiatan perekonomian yang unik dan menarik yang mempunyai potensi untuk dikembangkan beragam komponen kepariwisataan. Hal yang paling penting dalam pengembangan parwisata jenis ini adalah keaslian, keunikan, ciri khas daerah, dan rasa bangga yang terwujud dalam gaya hidup masyarakatnya. Misalnya tentang tata ruang desa, warisan budaya, pertaniannya, bentang alam, peristiwa sejarah maupun budaya yang dimiliki desa tersebut. Semua ini dapat menjadi daya tarik yang khas bagi para wisatawan.

Pariwisata dapat terjadi karena wisatawan pada dasarnya memiliki kebutuhan untuk menikmati daya tarik wisata yang tidak mereka temukan di tempat asalnya. Berdasarkan daya tariknya pariwisata pada umumnya dapat dibedakan menjadi tiga bagian yaitu; daya tarik alam, daya tarik budaya dan daya tarik minat khusus.

Daya Tarik Alam merupakan wisata yang dilakukan dengan mengunjungi daerah tujuan wisata yang memiliki keunikan daya tarik alamnya, seperti laut, pesisir pantai, gunung, lembah, air terjun, hutan dan objek wisata yang masih alami. Para wisatawan melakukan wisata ini pada umumnya disamping karena keunikan juga karena keindahannya. Syafiie (2009) menggolongkan daya tarik alam ini sebagai bagian dari daya tarik keindahan. Daya tarik keindahan dapat dilihat dalam dua bentuk, yang pertama adalah keindahan ciptaan 
Tuhan yang berupa daya tarik alam yang unik dan indah seperti yang sudah dicontohkan di atas, dan yang kedua adalah daya tarik keindahan buatan manusia seperti misalnya karya-karya seniman baik yang berupa bangunan yang megah dan indah maupun dalam bentuk karya-karya lainnya seperti; lukisan, nyanyian, drama, film, ukiran dan yang lainnya.

Daya Tarik yang kedua adalah daya tarik budaya. Daya tarik ini dapat menimbulkan suatu wisata yang dilakukan dengan mengunjungi tempat-tempat yang memiliki keunikan atau kekhasan budaya, seperti kampung naga, tanah Toraja, Kampung Adat Banten, Keraton Kasepuhan Cirebon, Keraton Yogyakarta, dan objek wisata budaya lainnya.

Syafiie, 2002 juga menyebutkan salah satu daya tarik wisata sebagai daya tarik budaya. Budaya didefinisikan sebagai kemampuan akal budi seseorang atau sekelompok manusia. Lebih lanjut dikatakan bahwa banyak orang melakukan kegiatan wisata yang dikarenakan daya tarik budaya dari suatu daerah apalagi kalau budaya tersebut sangat berbeda dengan budaya mereka. Bahkan bisa sebaliknya kalau mereka menemukan budaya yang sama di tempat yang jauh dan berbeda, hal ini tentuya menjadi daya tarik tersendiri bagi mereka, atau malah menimbulkan keheranan dan ingin mengetahui mengapa persamaan tersebut bisa terjadi.

Daya tarik yang ketiga adalah daya tarik minat khusus. Pariwisata ini merupakan pariwisata yang dilakukan dengan mengunjungi objek wisata yang sesuai dengan minat seperti wisata olah raga, wisata rohani, wisata kuliner, wisata belanja, dengan jenis-jenis kegiatannya antara lain, olah raga gantole, bungee jumping, dan kegiatan lainnya (Syafiie, 2002)

\section{Paket Wisata Bersepeda}

Paket wisata adalah suatu tour yang direncanakan dan diselenggarakan oleh travel agent atau tour operator dimana susunan acara, durasi tour, tempat-tempat yang dikunjungi, akomodasi termasuk makanan dan minuman sudah ditentukan dengan satu harga tertentu pula. Dengan kata lain bahwa dalam satu kali pembayaran kita dapatkan semua pelayanan yang ditawarkan tersebut (Yoeti, 1997).

Reily (dalam Suyitno, 2001) memberikan difinisi paket wisata dalam bahasa Inggris yaitu, all of the services a tour member purchases when paying for a tour. Typically, this includes accommodation, some meals, sightseing, some entertainments, poterage, an escort and other items. Air may or may not be included. Yaitu, semua pelayanan yang akan didapatkan oleh seorang peserta dengan satu bayaran tour, khususnya mencakup pelayanan akomodasi, makanan dan minuman. Melihat pemandangan, hiburan, pengangkutan barang bawaan, antar-jemput dan yang lainnya, mungkin juga termasuk tiket pesawat udara.

Paket wisata dapat dibedakan menjadi beberapa jenis berdasarkan perencanaan bagaimana paket wisata itu dibuat. Travel agent atau tour operator pada umunya menjual paket wisata yang sudah jadi. Dalam pembuatan paket ini pengelola tidak menunggu permintaan dari calon peserta dan jumlahnya ditentukan berdasarkan kebijakan si pengelola dengan memperhitungkan faktor-faktor pendukung dari paket wisata tersebut Paket tour ini disebut Ready Made Tour Packcage (Suyitno, 2001)

Paket wisata yang kedua disusun berdasarkan atas permintaan calon peserta. Inisiatif tour ini berawal dari kinginan para calon peserta. Paket wisata seperti ini disebut Tailored Made Package Tour. Paket wisata ini kemungkinannya dapat disusun dalam tiga bentuk. Pertama paket wisata ini dapat disusun dari berbagai komponen wisata yang dijadikan satu produk. Kedua tour jenis ini juga dapat berupa penggabungan beberapa Ready Made Tour dan ketiga dapat berupa kombinasi harga CAT (confidential Agent's 
Tarrif) dengan fasilitas lainnya. (Suyitno, 2001).

Berbagai Jenis Paket wisata telah berkembang di Bali, salah satunya adalah paket wisata bersepeda di desa Petak Kaja Gianyar. Melihat paparan tentang paket wisata di atas, paket wisata bersepeda ini pada umumnya adalah paket wisata dalam katagori Ready Made Tour Package. Para peserta tour ini nampaknya hanya mengikuti program yang sudah disiapkan oleh para pengelola.

Paket wisata bersepeda juga pada dasarnya adalah bagian dari wisata olah raga. Wisata yang juga merupakan satu bentuk respon dari propaganda go gereen dan back to nature yang kini sedang marak hampir di seluruh dunia. Wisata olahraga dapat dilakukan dalam berbagai bentuk yang salah satunya adalah bentuk paket wisata bersepeda. Yang tujuan utamanya untuk menjaga stamina tubuh agar tetap fit. Ada kemungkinan diadakan di daerah pedesaan untuk mendapatkan udara yang lebih murni karena jauh dari polusi udara seperti di kotakota besar di Indoesia. Akan tetapi ada juga kemungkinan sebagai dukungan daripada pengembangan wisata pedesaan.

\section{METODE}

Penelitian ini bersifat deskritif kualitatif. Whitney dalam Nazir, 2005: 55 menjelaskan bahwa penelitian deskriptif adalah pencarian fakta dengan iterpretasi yang tepat. Metode yang dipakai dalam penelitian ini adalah survey yaitu untuk memperoleh fakta-fakta dari gejala yang ada dan mencari keterangan secara faktual. Tujuan pokok penelitian ini bukan untuk menguji suatu hipotesa akan tetapi untuk memecahkan masalah yang dituangkan dalam rumusan masalah dari penelitian ini (Sevilla: 1993).

Dalam proses menganalisis data yang sudah terkumpul melalui wawancara dengan menanyakan tingkat ketertarikan mereka terhadap daya tarik yang mungkin dapat disaksikan selama pelaksanaan tur bersepeda ini berlangsung. Dalam wawancara dengan pemandu wisata, ditanyakan data tentang pengelola paket wisata ini secara umum. Sedangakan kepada wisatawan ditanyakan sebelas daya tarik wisata untuk mendapatkan tingkat ketertarikan mereka pada masingmasing daya tarik wisata tersebut.

Jumlah informn yang berhasil diwawancarai adalah 15 (limabelas) orang. Jumlah ini dianggap memadai karena jawaban dari para peserta sudah jenuh yaitu hampir sama dari jawaban-jawaban informan sebelumnya. Walaupun jumlah peserta tur bersepeda ini rata-rata enam puluh sampai dengan seratus orang per hari tetapi untuk mendapatkan responden sebanyak ini dicari dalam jangka waktu tiga hari yaitu 5 (lima) orang setiap harinya. Hal ini dilakukan agar proses pencarian data tidak menggangu wisatawan pada saat berhenti di banjar Padpadan, Petak Kaja, dan waktu yang tersedia untuk mereka juga sangat terbatas. Secara umum para wisatawan ini tidak berkeberatan untuk diwawancarai dan memberikan informasi yang diperlukan, bahkan beberapa merasa sangat senang penelitian seperti ini diadakan.

\section{III.HASIL DAN PEMBAHASAN}

Untuk mendapatkan jawaban dari dua pertanyaan yang diajukan pada tulisan ini yaitu (1) Daya tarik apa saja yang diminati oleh wisatawan selama melakukan wisata bersepeda di desa Petak Kaja Gianyar? Dan (2) Sarana pendukung apa saja yang diinginkan oleh para wisatawan untuk tersedia demi kenyamanan mereka melakukan wisata bersepeda di daerah tersebut? maka berdasarkan observasi yang telah dilakukan disusunlah daftar pertanyaan yang akan ditanyakan langsung kepada para wisatawan melalui wawancara. Pertanyaan dirancang sedemikian rupa sehingga para wisatawan dapat menjawabnya dalam waktu yang relatif singkat.

Para wistawan merasakan ketertarikan pada keberadaan orang lokal (local people) yang dengan ramah menyapa mereka di 
sepanjang rute yang mereka lalui. Dari jawaban yang diberikan oleh sembilan puluh responden tersebut hampir seluruhnya mengatakan bahwa keberadaan penduduk lokal sangat menarik perhatian mereka pada tur ini. Tidak satupun yang menjawab tidak menarik, hanya dua orang yang mengatakan cukup menarik.

Kehidupan sehari-hari orang lokal (local people daily life) juga menarik bagi mereka karena kemungkinan besar rutinitas kehidupan para wisatawan tersebut seharihari sangat berbeda dengan kebiasaan penduduk lokal. Dari Sembilan puluh responden hanya satu orang yang menyatakan cukup menarik. Hal ini terjadi karena orang ini sudah terbiasa dengan kebiasaan penduduk seperti ini karena sudah sering berkunjung ke Bali.

Hampir semua responden juga sangat tertarik akan keindahan dan keunikan landscape kawasan ini, seperti perkampungan para penduduk yang diselingi perkebunan dan persawahan serta balai desa ataupun balai subak serta keberadaan pura-pura di setiap banjar. Walaupun tidak begitu istimewa bila dibandingkan dengan daerahdaerah lainnya. Hampir sama dengan apa yang didapatkan pada waktu observasi, mereka menemukan perkampungan penduduk yang diselingi dengan ladang atau persawahan serta pura, pasar kecil dan balai banjar sangat menarik perhatian mereka. Kontur jalan yang menurun yang dibatasi oleh air mengalir di parit juga sangat menarik bagi mereka. Dari Sembilan puluh wisatawan ini semua mengatakan bahwa item landscape beauty yang paling menarik

Bentang persawahan (rice field) sangat menarik bagi para responden, khususnya pada sistim pengolahaannya. Mereka terkagum-kagum dengan sistem irigasi penduduk lokal bahkan sangat terkejut ketika mengetahui bahwa batas tanah petani tidak ada tanda yang jelas, hanya berdasarkan ingatan saja.

Upacara adat dan pertunjukanpertunjukan kebudayaan setempat (local ceremonies and culture events). Item ini ditanyakan karena menurut pengamatan awal, para wisatwan tersebut sering berhenti dan dengan senang melihat-lihat upacara adat yang kebetulan mereka temui. Pada saat pencarian data ini kebetulan ada beberapa upacara pernikahan yang dapat para wisatawan tersebut temui di sepanjang rute bersepeda mereka, sehingga item ini mendapatkan respon sangat menarik bagi mereka. Dari Sembilan puluh orang responden itu hampir semuanya menyebutkan hal ini sangat menarik hanya beberapa orang saja yang membilang cukup menarik. Hal ini tentunya dikarenakan oleh pada saat hari kedua dan ketiga pencarian data upacara pernikahan tersebut sudah selesai.

Lalu lintas pedesaan (village traffic) juga ditanyakan, karena para wisatawan tersebut bersepeda menggunakan jalan pedesaan yang juga dipakai oleh masyarakat, tidak menggunakan jalur khusus. Dari Sembilan puluh responden hanya beberapa orang yang mengatakan bahwa lalu lintas pedesaan sangat kuarang baik (menarik). Walaupun sebagian dari mereka mengatakan tidak apaapa dengan kondisi lalu lintas tersebut tetapi dari hasil wawancara bisa disimpulkan mereka cendrung ingin mengatakan lalu lintas pedesaan tidak teratur. Hal ini dapat dibenarkan karena ada banyak kendaraan di jalan pedesaan yang melaju dengan cepat, banyak juga anak-anak sekolahan yang mengendarai sepeda motornya dengan kebutkebutan yang akan sangat mengganggu kegiatan tur bersepeda ini.

Environment cleanliness atau kebersihan lingkungan. Dari Sembilan puluh orang responden, hampir menemukan suatu kesepakatan bahwa lingkungan pedesaan di sepanjang rute tur bersepeda ini sangat kurang bersih. Kebanyakan wisatawan yang mengikuti tur bersepeda ini berasal dari Negara-negara di Eropa, Amerika, dan Australia yang pada dasarnya memiliki standar keberihan dan sanitasi yang tinggi. Bahkan bererapa dari mereka memberikan masukan "clean up any rubbish", ataupun "I hate plastic rubbish everywhere". Dapat 
disimpulkan bahwa kebersihan lingkungan ini merupakan hal yang paling tidak menarik bagi mereka.

Village houses (rumah-rumah pedesaan) tentunya pasti ada perbedaan dengan rumahrumah di pedesaan di negara mereka. Dari Sembilan puluh responden lebih dari separuhnya mengatakan sangat menarik dan sebagiannya lagi mengatakan cukup menarik. Tetapi dari penggalian informasi lebih dalam banyak dari mereka yang mengatakan cukup menarik sehingga dapat disimpulkan bahwa hal ini juga menarik perhatian mereka.

Quality of country road (kualitas jalan pedesaan) adalah hal yang ketiga yang menurut penilaian mereka paling tidak menarik (bagus). Walaupun jalan di pedesaan ini adalah hotmik, akan tetapi karena pada saat penelitian ini diadakan masih banyak bagiannya yang rusak, sehingga mendapat penilaian seperti ini.

Villge temples (pura di pedesaan), dari Sembilan puluh responden sebagian besar mengatakan bahwa pura yang kebetulan mereka lihat di sepanjang rute adalah menarik perhatian mereka.

Village schools (sekolah-sekolah di pedesaan). Hal ini ditanyakan karena pada saat penjajagan ditemukan banyak anak sekolahan di pedesaan ini berpapasan dengan para tamu tersebut pada saat pulang sekolah. Jadi mereka masih menggunakan seragam sekolahnya pada saat memberi salam kepada para tamu yang bersepeda di jalan yang menjadi rute cyling tour itu. Dari sembilan puluh responden juga seperti membuat kesepakatan bahwa village school menarik bagi mereka. Beberapa orang dari mereka yang berprofesi sebagai guru sangat ingin mendapatkan waktu lebih lama untuk melihat kegiatan pembelajaran di sekolah-sekolah di pedesaan tersebut.

Selain ke sebelas pertanyaan di atas para wisatawan juga diminta untuk menyebutkan item item lain yang belum ditanyakan dan sekaligus memberikan tingkat ketertarikan mereka pada item item tersebut. Dari Sembilan puluh responden, hampir semuanya membilang sudah cukup, hanya satu yang menambahkan yaitu item local art music yang sangat menarik bagi nya. Wisatawan yang lain mungkin sudah menggolongkan item ini ke dalam local ceremony/culture events

Terakhir, wisatawan diminta untuk menyebutkan fasilitas-fasilitas apa saja yang menurut mereka hendaknya disediakan demi kenyamanan bersepeda mereka. Banyak dari mereka yang malah memberi komentar yang sangat positif tentang tur ini dengan mengatakan; "all great", "everything is perfect", "love everything", "very good tour", "tour is perfect, great job", "it's all good"

Beberapa dari mereka menginginkan ketersediaan air bersih pada saat berhenti di banjar Padpadan desa Petak kaja ini. Walaupun mereka bisa menyewa toilet di sebuah rumah penduduk setempat tapi dikatakan belum memenuhi standar kebersihan dan sanitasi. Beberapa dari mereka berpendapat bahwa rute bersepeda mereka sepertinya bukanlah jalanan yang normal seperti off road saja, akan tetapi mereka sangat tertarik pada tantangan ini.

Hal lain yang juga mereka inginkan tidak berhubungan dengan daya tarik pedesaan tetapi pada kenyamanan berkandaraan karena beberapa dari mereka meminta agar disediakan sabuk pengaman di kendaraan yang mengantar dan menjemput mereka. untuk melakukan tur ini. Selain itu banyak dari mereka yang memuji tour guide mereka. dengan mengatakan; "very good tour guide, hope they help local people", "tour guide is very important, must be enthusiastic", "good guide", "tour guide Ketut is very good".

\section{SIMPULAN}

Berdasarkan dari hasil pembahasan di atas maka dapat ditarik beberapa kesimpulan sebagai berikut:

Para wisatawan tertarik pada keindahan bentang alam pedesaan di daerah desa Petak Kaja dan sekitarnya. Mereka juga tertarik 
pada bererapa hal yang mereka lihat di Desa Petak Kaja dan sekitarnya seperti: keberadaan penduduk lokal, kehidupan penduduk lokal sehari-hari, persawahan, upacara adat dan pertunjukan budaya setempat, dan perumahan penduduk. Para wisatawan juga memiliki ketertarikan pada pura (tempat persembahyangan umat Hindu) dan sekolah-sekolah di desa Petak Kaja dan sekitarnya.

Fasilitas yang dinginkan tersedia untuk kenyamanan tur bersepeda ini adalah air bersih dan toilet yang bersih dan higenis di tempat berhenti dan di tempat tur ini berakhir. Walaupun mereka bisa menyewa toilet di rumah penduduk akan tetapi belum sesuai dengan harapan mereka. Tesedianya sabuk pengaman pada kerdaraan yang mengantar dan menjemput mereka juga mendapatkan perhatian dari beberapa informan.

\section{REFERENSI}

Adhisakti L. T. 2000, Strategi Pengembangan Desa Wisata di Indonesia. Dalam makalah seminar Nasional Pemberdayaan pariwisata berdbasi Kerakyatan dalam Menyongsong Otonomi Derah Bali.

Korten. D. C. Ed. 1986. Community Management. Asian Experience and Perspective. Connecticut: Karamian Press.

Kusmayadi \& Sugiarto, E. 2000. Metodelogi Penelitian bidang kerariwisataan. Jakarta: Gramedia Pustaka Utama.

Malhotra, N. K. 2005. Riset Pemasaran, Pendekatan Terapan. Edisi keempat. Jilid kesatu. Jakarta: PT. Indeks Kelompok Gramedia.

Michael, VT King, and MJG Parnwell (eds). 1993: Tourism In Southeast Asia, Londn and New York: Routledge.

Nasir, 2005. Metode Penelitian. Jakarta: Ghalia Indonesia.

Sevilla, G. S. dkk. Pengantar Metodologi Peneliatian: Jakarta Universitas Indonesia Press.

Suprastayasa, I G. N. A. 2007. Pariwisata dan Kemiskinan di Bali. Jurnal Kepariwisataan (6) 2. 123 - 131

Suyitno. 2001. Perencanaan Pariwisata. Yogyakarta: Kanisius.

Syafiie. H. I.K. 2009. Pengantar Pariwiasata. Bandung: Penerbit Bandar Maju.

Undang-Undang Nomor 10 tahun 2009. Tentang Kepariwisataan. Jakarta.

Wiranatha A. S. \& Astawa. I. B. G. P 2008. Analisis Pasar Wisata Bali. Denpasar: Dinas Pariwisata Propinsi Bali.

Wirata. I. N. 2010. Pariwisata Pedesaan sebagai Paket Wisata Alternatif. Kasus Desa Wisata Taman Slau. Jurnal Kepariwisataan, 9 (2) STP Nusa Dua Bali.

Wirawan, K. (2016). Wisata Sepeda Dalam Mewujudkan Pariwisata Berkelanjutan di Sanur. Jurnal Master Pariwisata JUMPA, 2 (2): 1 - 16. doi: 10.24843/JUMPA.2016.v02.i02.p01 